\title{
Correlate of Resource Utilization and Students' Learning Outcome in Colleges of Education in South West Nigeria
}

\author{
W. O. Ibukun \\ Department of Educational Management, Faculty of Education \\ Adekunle Ajasin University, PMB 001, Akungba-Akoko, Ondo State, Nigeria \\ Tel: 234-803-726-1162_E-mail: ibukunoluwa2009@yahoo.com \\ C. A. Akinfolarin \\ Department of Educational Management, Faculty of Education, \\ Adekunle Ajasin University, PMB 001, Akungba-Akoko, Ondo State, Nigeria \\ Tel: 234-803-712-0234 E-mail: ajoro123@yahoo.com \\ O. S. Alimi \\ Department of Educational Management, Faculty of Education \\ Adekunle Ajasin University, PMB 001, Akungba-Akoko, Ondo State, Nigeria \\ Tel: 234-806-113-7511_E-mail: alimiolatunji@yahoo.com
}

Received: March 11, 2011 Accepted: March 21, 2011 doi:10.5539/ies.v4n3p178

\begin{abstract}
This study investigated resource utilisation in vocational and technical education as a correlate of student learning outcome in selected colleges of education in south west Nigeria. The study examined the relationship between time, space and physical resource utilisation and perceived student learning outcome. The study used the descriptive research design of the survey type. The sample for the study was 687 students. Stratified and simple random sampling techniques were used to select the sample. Student questionnaire on correlate of resource utilisation and perceive student learning outcome was the instrument used to collect data for the study. The data collected were analysed using Pearson Product Moment Correlation and Multiple Regressions. All the hypotheses were tested at 0.05 level of significance. The study reveals that most of the physical resources were well utilised. Time for various activities in vocational and technical education were well utilised except in extra curricular activities and students forum. The perceived students learning outcome was high. There was a significant relationship between resource utilisation and perceived students learning outcome. Time, space and physical resource utilisation were significantly related to perceived students learning outcome. Recommendations were made based on the findings.
\end{abstract}

Keywords: Resource Utilization, College of Education, Vocational and Technical Education, Descriptive Study, Pearson Correlation, Regression, Nigeria

\section{Introduction}

Utilization of resources in an organization is as important as the achievement of goals and objective. Students learning outcome is not likely to be known or observed without using the appropriate resources effectively and appropriately. Student learning outcome could be observed to be relatively changed in the behaviour of the learner. Abayomi and Olukayode (2006) state that learning is something students do, not something that is done to students. They further agreed that learning requires student's direct and active involvement and participation. Ibe-Bassey (2002) agrees that learning is an altered disposition in an individual as a result of instruction; it is distinguished from motivation, growth and needs. Using the above definition of learning, it could be observed that Vocational and Technical Education induces individual students to learn by involving themselves in critical thinking and participating actively in a given task. Inwang (1985) is of the opinion that Vocational and Technical Education is the study of technologies and related sciences and acquisition in practical skill knowledge relating to occupation of various sectors of the economic and social life were all espoused in Vocational Education. He further agreed that 
Vocational Education helps to fix right habits of thinking and doing in students through repetitive training, carried out to the extent where it gives the trainee a productive ability with which he or she can secure employment. Student learning outcome are likely to be practically seen in Vocational and Technical Education where students discovered and do things themselves.

In broad sense, Vocational and Technical Education could be part of the total experience of the individual whereby he learnt successfully to carry on a gainful occupation. It offers knowledge of the practices essential for skill development. Vocational Education in this sense does not only rely merely on imitation, observation or incident participation but on organized instruction. Thus, the teachings of Vocational and Technical courses in schools are classified as organised Vocational Education. In line with this, Federal Republic of Nigeria (2004) supports that Technical Education covers the prescribed learning activities in Pre-Vocational and Vocational schools at Post-Primary levels, the Technical Colleges, the Polytechnics and Technical Education at Post-Secondary level of which Colleges of Education is one. From this statement therefore, Technical Education leads to the acquisition of practical and applied skills as well as basic scientific knowledge.

The student learning outcome in Vocational and Technical Education was observed largely to be dependent on availability and utilization of resources, because Vocational Education teaches an individual the basic principle of doing things. Also the students are trained to acquire saleable skills using these resources. There are many important resources to be utilized in achieving a set goal and objective. Okorie (2001) observes that Nigeria is rich in natural resources such as minerals, forest products, animal life, water and good soil. In other to develop these resources, professional and technical know-how is needed. He further suggested that more good teachers, scientist, technicians, mechanics and maintenance workers of all kinds must be trained. He also emphasized that there should be need for skilled engineers to design and install new and improved equipment. Ayeni (2005) identifies some factors that are responsible for the poor learning outcome of students in Vocational and Technical Education. These include inappropriate planning of educational programme; insufficient qualified vocational educators in the field, insufficient material resources for training, lack of recognition and encouragement of Vocational education graduates, inadequate funding and lack of vocational researchers. Olaitan (1994) states the following factors to be the probable causes of poor learning outcome: the poor utilization of resources; poor teaching methods; students' attitude toward Vocational and Technical Education and societal negative attitude towards the subject. This study observed that the cognitive aspect of learning was stressed in Vocational and Technical Education curriculum of colleges of Education. This might have contributed to the derogatory attitude of students toward the vocational and technical education courses and consequently their poor performance in Vocational and Technical Education courses. It is no gainsaying that the effective teaching and learning of vocational and technical education courses depend greatly on adequacy of human, maternal and physical resources.

The insufficient physical and material resource for training is another factor responsible for leaning outcome of students. Experiences show that some of the Colleges of Education do not have enough and standard workspace such as workshops, laboratories, classrooms or lecture theatre to train the students, while some consumable and non consumable materials needed for practical exercises are not available, some of the available material resources in some of these colleges of education appear not to be functioning.

Some of the above indicators of poor leaning outcome in Vocational and Technical Education are closely linked with poor utilization of resources in different ways. In another dimension, the shortage of skilled and qualified vocational educators may affect the poor utilisation of resources. Federal Republic of Nigeria (2004) states categorically that no education can rise above the quality of its teachers. It was observed that majority of the vocational educators are not exposed to some of the new sophisticated machines during training. Hence, some of the lecturers do not know the technical know-how or the way to operate some of the equipment. Other notable observered factor is the inadequate funding of Vocational and Technical Education which may lead to insufficient material resources for training. In some Collages of Education, the few resources that are available are old and not properly mounted due to lack of fund. All these may affect the utilisation of material resources in South West Collages of Education. Undoubtedly, underutilisation or over utilisation of time, insufficiency and lack of resources in the South West Colleges of Education would continue to worsen the students learning outcome. Hence this study is carried out to know if there is any correlation between resources utilisation in Vocation and Technical Educational (V. T .E) and students learning outcome in selected Collages of Education in South West Nigerian.

\section{Purpose of the Study}

This study is set to investigate the relationship between resource utilisation and perceived students learning outcome in Vocational and Technical Education in College of Education South West Nigeria.

Based on the problem of this study a general question was raised: 
1 What is the perceived students Learning outcome in Colleges Education South West Nigeria?

\section{Hypothesis}

The following null hypothesis were raised for this study.

i) There is no significant relationship between time utilisation and perceived student learning outcome.

ii) There is no significant relationship between space utilisation and perceived students learning outcome.

iii) There is no significant relationship between physical resources utilisation and perceived students learning outcome

iv) Resource utilisation factors will not significantly contribute to perceived students learning outcome.

\section{Method}

This study was a descriptive research of the survey type. All academic staff and students of school of Vocational and Technical Education in Colleges of Education in South West Nigeria were the population. As at this study, there were the 11 (eleven) Colleges of Education in the South West Nigeria: four (4) Federal Colleges and seven (7) state Colleges of Education.

The sample for this study was made up of 687 students which were selected using stratified and simple random sampling techniques: stratified random sampling technique was used to select 8 Colleges of Education, these consisted of three (3) Federal and five (5) state Colleges of Education. Data for this study were mainly through the use of inventory and questionnaire. Students Questionnaire on Resource Utilization in Vocational and Technical Education in South West Nigeria. (SQRUVTE) was the instrument used to collect data for this study. The instrument was validated by experts in the departments of Educational Management and Test and Measurement of Adekunle Ajasin University Akungba Akoko. The reliability test of SQRUVTE was 0.818 which was considered high enough to be reliable. The total numbers of questionnaires administered on students were 740. out of which 687 copies representing 92.8\% were duly completed and returned. Pearson Product Moment Correlation was employed for the testing of hypotheses 1, 2, 3 at 0.05 level of significance Multiple Regression Analysis was used for hypothesis 4 .

\section{Results}

What is the students' perceived learning outcome?

Table 1 reveals that $83.3 \%$ respondents indicated that the concepts gained were high, $82.7 \%$ agreed that retention memory was high, $81.5 \%$ were of the opinion that the knowledge of principles acquired during lectures were high, and learning experience shared with colleagues are also high; $80.6 \%$ respondents indicated that appreciation of societal values and saleable skills acquired as students are very high. Ability to abide by the college rules and regulations and ability to use available resources during practical examination both had $78.6 \%$ high. The average percentage of perceived students' learning outcome was $79.5 \%$ high. The result therefore reveals that perceived students' learning outcomes was high.

Hypothesis 1: There is no significant relationship between time utilization and perceived students' learning outcome.

Data collected on items related to time utilization such as time for theoretical lectures, practical activities, industrial training, time on the time table, time for examination, extra curricular activities and student learning outcomes were scored and correlated. The result obtained is as presented in table 2 below.

Analysis of result in table 2 reveals that $r$ cal (0.471) is greater than $r$ table (0.195). Therefore, the null hypothesis is rejected. This means that there is a significant relationship between time utilization and perceived students' learning outcome.

Hypothesis 2: There is no significant relationship between space utilisation and perceived students' learning outcome.

Data collected on items on space utilisation are classroom space, workshop, laboratory, staff office, library, auditorium, lecture theatre, internet facility, and space were scored and correlated with perceived students' learning outcome. The result is as presented in table 3 below.

Table 3 reveals that $r$-cal $(0.433)$ is greater than $r$-table $(0.195)$. Therefore, the null hypothesis which states that there is no significant relationship between space utilisation and perceived students' learning outcome is rejected. This means there is a significant relationship between space utilisation and perceived students' learning outcome. 
Hypothesis 3: There is no significant relationship between physical resources utilisation and perceived students learning outcome

Responses to items on physical resource utilisation and perceived students' learning outcome were scored and then correlated. The physical resources include tools and equipments, buildings where these equipments are stored and used in different departments such as Agric science, Business studies, Fine and applied arts, Home Economics and Technical education. The result is as shown in table 4 below.

The result in Table 4 shows that the value of r-calculated (0.255) is greater than r-table (0.195). Therefore, the null hypothesis which states that there is no significant relationship between physical resource utilisation and perceived students' learning outcome is rejected. This means there is a significant relationship between physical resource utilisation and perceived students' learning outcome.

Hypothesis 4: Resource utilisation factors will not significantly contribute to perceived students' learning outcome.

Regression Equation Formula

$$
Y=\alpha+\beta_{1} X_{1}+\beta_{2} X_{2}+\beta_{3} X_{3}
$$

where: $\mathrm{X}_{1}, \mathrm{X}_{2}, \mathrm{X}_{3}$ are independent variables or predictors

$$
\begin{aligned}
\mathrm{Y}= & \text { Dependent variable } \\
\beta & =\text { Coefficient of Multiple Regression } \\
\alpha & =\text { Constant } \\
\mathrm{SLO}= & 21.065+0.024 * \mathrm{PRU}+0.379 * \mathrm{TMU}+0.096 * \mathrm{SPU}
\end{aligned}
$$

$\mathrm{SLO}=$ Students' Learning Outcome

$\mathrm{PRU}=\quad$ Physical Resource Utilisation

$\mathrm{TMU}=$ Time Utilisation

SPU $=$ Space Utilisation

The coefficient of determination as revealed in table 5 was 0.227 . By implication, $22.7 \%$ of the variance is attributable to the joint effect of the predictor variables. The remaining $76.3 \%$ variation is as a result of other variables outside the regression equation to the criterion variable. From table 5, the analysis of variance shows that contribution of resource utilisation factors to perceived students' learning outcome is significant.

A cursory look into the result reveals the relative contribution of each of the predictor variables (time utilisation, space utilisation and physical resource utilisation) to the criterion variable as the beta weight of 0.379 (38\%) for time utilisation, shows to be the best contributor. This was followed by space utilisation with a beta weight of 0.096 $(10 \%)$, while physical resource utilisation shows the least contribution with a beta weight of $0.024(2.4 \%)$.

It was found that there was significant relationship between physical resources utilisation and perceived students' learning outcome. This could be attributed to the fact that befitting physical resources/facilities do encourage students to learn. This result corroborates Fagbemi, (1988); Bajah (1979); Ogunniyi (1982); who claime that physical resources such as laboratories, workshops and other facilities influenced perceived students' learning outcome.

The result of hypothesis five revealed that the predictor variable (physical resource utilisation, time utilisation and space utilisation) have significantly contributed to the dependent variable (perceived students' learning outcome). This could be attributed to the fact that many resources used at a time help the learners to understand and get facts assimilated easily. This finding is in support of Thomas and John (1977) who state that managers utilize many resources like raw materials, building and financial resources to accomplish their goal. It is arguable that space, time and other physical facilities are the major contributors to perceived students' learning outcome.

\section{Conclusion}

Based on the findings of the study, the following conclusions are drawn.

$>$ Most of the required resources in Vocational and Technical Education were available and adequate.

$>$ Physical resource utilisation, space utilisation and time utilisation were related to perceived students' learning outcome in Vocational and Technical Education.

$>$ The students were of the opinion that utilisation of resources in Vocational and Technical Education enhances their learning outcome. 
Time utilisation is the best predictor of perceived students' learning outcome in Vocational and Technical Education.

\section{Recommendations}

Based on the findings and conclusion of this study, the following recommendations were made:

$>$ Laboratory spaces, departmental stores and general stores should be more utilised by the schools of Vocational and Technical Education in the Colleges of Education in South West Nigeria.

$>$ Physical resources such as drawing room equipment, duplicating and binding machines; and technical drawing equipment should be well utilised in Colleges of Education in the South West Nigeria.

> Time for extra-curricula activities and students forum should be well utilised.

> Time utilisation, space utilisation and physical utilisation should be improved upon in order to improve perceived students' learning outcome.

\section{References}

Abayomi, \& Olukayode. (2006). Effects of Cooperative and Competitive learning strategies on students' performance in Mathematics. The Nigerian Journal of Guidance and Counselling, 11(1):60-69, Ilorin Nigeria.

Ayeni, M.F. (2005). The Role of Vocational and Technical Education in National Development. Journal of Research in Vocational and Education,.2 (1) : 111-117, Ikere-Ekiti

Bajah, S.T. (1979). Correlates of Students Extrinsic School Environment Factors with level of Attainment in Chemistry, Journal of Science Teacher Association of Nigeria.

Fagbemi, B. O. B. (1988). Technological Education in Nigeria: An Overview of Its Historical Development, Role and Function. Nigerian Journal of Technical Education, 5 (1\& 2): 33-39

Federal Republic of Nigeria. (2004). National Policy on Education (Revised) Lagos: Nigerian Educational Research and Development Council (NERDC).

Ibe-Bassey, G.S. (2002). Principles and Practice of Instructional Communications in Nigeria, Dorand Publishers.

Inwang, I. I. (1985). The New Educational Policy and the Future of Technical and Vocational Education. A Paper Presented at the National Workshop on Problems and Implication of 6-3-3-4 National Policy on Education in Zaria July, 8-12

Ogunniyi, M.B. (1982). Teaching and learning of primary science. $24^{\text {th }}$ Annual Conference Proceedings of the Science Teachers Association of Nigeria (STAN) p.56

Okorie, J.U. (2001). Vocational Industrial Educational; League of Researchers in Nigeria (LRN) Bauchi.

Olaitan, S.O. (1994). Vocational Technical Education Systems in U.S.A, Great Britain and Japan: Lessons for Nigeria. Unpublished Paper Presented at a Workshop on Vocational and Technical Education as a Foundation for a Healthy Economy Organized by the Federal Development in Collaboration with UNESCO and Dornier International Logistics at Otta in Ogun State Nigeria.

Thomas, W. J., \& John, E. S. (1978). Managing Today and Tomorrow. Philippines: Addison-Wisely Publishing Company Inc. 12:111-120 
Table 1. Perceived Students' Learning Outcome

\begin{tabular}{|c|c|c|c|c|c|c|c|}
\hline \multirow[b]{2}{*}{$\mathbf{S} / \mathbf{N}$} & \multirow[b]{2}{*}{ Items } & \multicolumn{2}{|c|}{ High } & \multicolumn{2}{|c|}{ Low } & \multirow{2}{*}{$\frac{\text { TOTAL }}{\mathbf{f}}$} & \multirow{2}{*}{$\frac{\text { TOTAL }}{\%}$} \\
\hline & & $\mathbf{F}$ & $\%$ & f & $\%$ & & \\
\hline 1. & The impact of lectures received is & 497 & 72.3 & 190 & 27.7 & 687 & 100 \\
\hline 2. & $\begin{array}{l}\text { The knowledge of principles acquired } \\
\text { during lectures is }\end{array}$ & 560 & 81.5 & 127 & 18.5 & 687 & 100 \\
\hline 3. & The concepts gained is & 572 & 83.3 & 115 & 16.7 & 687 & 100 \\
\hline 4. & My retention memory is & 568 & 82.7 & 119 & 17.3 & 687 & 100 \\
\hline 5. & $\begin{array}{l}\text { Learning experience shared with } \\
\text { colleagues is }\end{array}$ & 560 & 81.5 & 127 & 18.5 & 687 & 100 \\
\hline 6. & $\begin{array}{l}\text { The level of relationship between me } \\
\text { and my lecturers are }\end{array}$ & 550 & 80.1 & 137 & 19.9 & 687 & 100 \\
\hline 7. & My appreciation of the societal values is & 554 & 80.6 & 133 & 19.4 & 687 & 100 \\
\hline 8. & $\begin{array}{l}\text { My contribution to the progress of the } \\
\text { college }\end{array}$ & 551 & 80.2 & 136 & 19.8 & 687 & 100 \\
\hline 9. & My relationship with other colleagues & 535 & 77.9 & 152 & 22.1 & 687 & 100 \\
\hline 10. & $\begin{array}{l}\text { My ability to abide by the college rules } \\
\text { and regulations is }\end{array}$ & 540 & 78.6 & 147 & 21.4 & 687 & 100 \\
\hline 11. & Saleable skills acquired as a student are & 554 & 80.6 & 133 & 19.4 & 687 & 100 \\
\hline 12. & Demonstrations at practical lessons are & 546 & 79.5 & 141 & 20.5 & 687 & 100 \\
\hline 13. & $\begin{array}{l}\text { My ability to use available resources } \\
\text { during practical examinations is }\end{array}$ & 540 & 78.6 & 147 & 21.4 & 687 & 100 \\
\hline 14. & $\begin{array}{l}\text { The skills acquired for entering into } \\
\text { higher institution is }\end{array}$ & 527 & 76.7 & 160 & 23.3 & 687 & 100 \\
\hline 15. & $\begin{array}{l}\text { Skills acquired for self-employment after } \\
\text { graduation is }\end{array}$ & 532 & 77.4 & 155 & 22.6 & 687 & 100 \\
\hline & Average & 546 & 79.4 & 141 & 20.6 & 687 & 100 \\
\hline
\end{tabular}

Table 2. Pearson Correlation summary of Time Utilisation and Perceived Students' Learning Outcome

\begin{tabular}{|c|c|c|c|}
\hline Variable & $\mathbf{N}$ & $\mathbf{r}_{\text {cal }}$ & $\mathbf{r}_{\text {table }}$ \\
\hline Resource utilisation & 687 & \multirow{2}{*}{0.471} & \multirow{2}{*}{0.195} \\
\cline { 1 - 2 } Perceived students' learning outcome & 687 & & \\
\hline
\end{tabular}

$\mathrm{P}<0.05$ 
Table 3. Pearson Correlation Summary of Space Utilisation and Perceived Students' Learning Outcome.

$\mathrm{P}<0.05$

\begin{tabular}{|c|c|c|c|}
\hline Variable & $\mathbf{N}$ & $\mathbf{r}_{\text {cal }}$ & $\mathbf{r}_{\text {table }}$ \\
\hline Space utilisation & 687 & 0.433 & 0.195 \\
\hline Perceived students' learning outcome & 687 & & \\
\hline
\end{tabular}

Table 4. Pearson Correlation Summary of Physical Resource Utilisation and Perceived Students' Learning Outcome

\begin{tabular}{|c|c|c|c|}
\hline Variable & $\mathbf{N}$ & $\mathbf{r}_{\text {cal }}$ & $\mathbf{r}_{\text {table }}$ \\
\hline Physical resource utilisation & 687 & 0.255 & 0.195 \\
\cline { 1 - 2 } Perceived students' learning outcome & 687 & & \\
\hline
\end{tabular}

$\mathrm{P}<0.05$

Table 5. Multiple Regression Analysis of resource Utilisation factors with learning outcome as dependable variable

\begin{tabular}{|c|c|c|c|c|c|c|}
\hline & Variables & B & $\begin{array}{c}\text { Standard } \\
\text { Error }\end{array}$ & Beta & t & Sig. \\
\hline Multiple $\mathrm{R}^{2}=0.477$ & Constant & 21.065 & 1.973 & & 10.674 & 0.000 \\
\hline $\mathrm{R}^{2}=0.277$ & $\begin{array}{c}\text { Physical Resource } \\
\text { Utilisation }\end{array}$ & 0.04117 & 0.068 & 0.024 & 0.603 & 0.547 \\
\hline Adjusted $\mathrm{R}^{2}=0.224$ & Time Utilisation & 0.865 & 0.153 & 0.379 & 5.665 & 0.000 \\
\hline Standard Error $=15.976$ & Space Utilisation & 0.150 & 0.107 & 0.096 & 1.400 & 0.162 \\
\hline
\end{tabular}

